\title{
遮水性材料を併用した高機能舗装の 基層部損傷抑制効果に関する一考察
}

\author{
松本 大二郎 $^{1} \cdot$ 加藤 亮 $^{2} \cdot$ 佐藤 正和 ${ }^{3} \cdot$ 神谷 恵三 ${ }^{4}$ \\ 1 非会員 (株)高速道路総合技術研究所 舗装研究室主任（干194-8508 東京都町田市忠生 1-4-1） \\ E-mail:d.matsumoto.aa@ri-nexco.co.jp \\ 2 正会員 (株高速道路総合技術研究所 舗装研究室主任（广194-8508 東京都町田市忠生 1-4-1） \\ 3 正会員 (株高速道路総合技術研究所 舗装研究室長 ( T194-8508 東京都町田市忠生 1-4-1) \\ 4 正会員 博 (工) (株高速道路総合技術研究所 舗装研究部長（干194-8508 東京都町田市忠生 1-4-1)
}

\begin{abstract}
高濃度改質アスファルト乳剂または特殊改質アスファルトを併用し, 高機能舗装混合物の下層に遮水性を 持たせる工法について，基層部の損傷抑制効果等の評価を試みた。実物大の供試体を用いた実験結果から， 通常工法に比へ，基層に損傷が無く舗装構造が健全な場合には，はく離進行抑制効果を有することを確認し た。しかし，基層に損傷がある場合は，損傷程度が比較的低い段階までは，急速な損傷の進行は緩和される 可能性があるものの，繰返しの交通荷重の作用により基層の損傷が進行していくことを確認した。これらの 結果を踏まえ, 本工法の適用について考察した.
\end{abstract}

Key Word : porous asphalt surface layer, highly concentrated modified emulsion, modified asphalt, binder layer, segregation

\section{1. はじめに}

高機能（ポーラスアスファルト）舗装は，東日本高速 道路(株)，中日本高速道路(株)，西日本高速道路株）(以下， NEXCO という)により運営管理されている高速道路の舗 装の標準的な表層混合物として使用されており，全車線 面積の 7 割を超える施工実績を有している．高機能舗装 については，舗装体内の連続した空隙により，密粒度舗 装に比べ雨天時の水はねやスモーキング現象が軽減され, 視認性やすべり抵抗が向上する．また，タイヤ騒音が軽 減するなどの特徴を有する。しかし, 雨水を基層上面に 滞留・流下させることから，特に切削オーバーレイ工等 により既設基層の補修を行わず，表層に高機能舗装混合 物を施工した場合，基層混合物の状態によっては，はく 離に起因したポンピングや局部流動といった高機能舗装 特有の損傷 ${ }^{1)}$ が供用後比較的早期に顕在化する場合があ る.

近年，高機能舗装混合物の下層に通常使用されている ゴム入りタックコート（PKR-T） と異なる性状・散布量 の材料で形成された層を構築することで, 上記損傷の要 因となる基層への水の浸透を抑制させる工法（以下，遮 水型工法という）が開発されており，NEXCO でも，主に 舖装修繥の現場において，既設基層を活用 (存置) する
ことによるコスト縮減を目的とした遮水型工法の施工事 例が散見されるようになっている.

一方，遮水型工法の性能については，現状において， 統一的に定められた基準等がなく，同一の尺度で効果を 確認することができない. また, 既設基層の状態によっ て，効果が異なってくることが考えられる.

このような背景から，(株)高速道路総合技術研究所（以 下，NEXCO 総研という）では，実物大の舗装構成で，大 型車の載荷重により走行実験を行うことが可能な回転式 舗装試験機（NEXCO 総研保有）を使用し，通常工法と数 種類の遮水型工法について各種の実験を行い，基層部の 損傷抑制効果の評価を試みた。また，高速道路本線で遮 水型工法が施工された箇所において, FWD 測定による追 跡調査を実施し，アスファルト層の構造的な強度への影 響等について評価を行った。

本文は，これらの結果等に基づき，遮水型工法の基層 部損傷抑制効果について考察する.

\section{2. 遮水型工法の概要}

図-1 に本研究で扱う遮水型工法の概念を示す. 遮水型工法に使用されている材料は，高濃度改質アス 


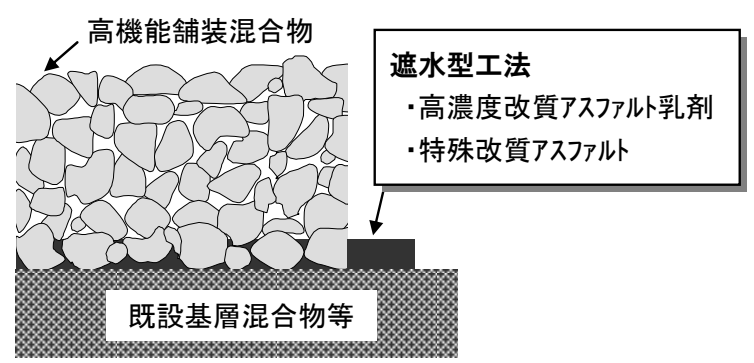

図-1＼cjkstart遮水型工法の概念

表-1 遮水型工法の種類

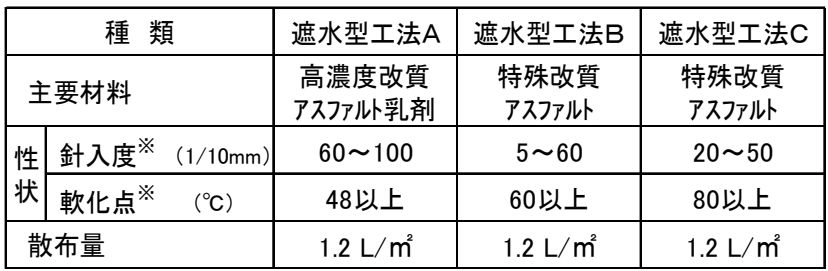

※ 製品規格値,「遮水型工法 $A$ 」は蒸発残留物での値

ファルト乳剂または特殊改質アスファルトであり，一般 的な散布量は，概ね 1.2L $/ \mathrm{m}^{2}$ となっている。この多量に散 布される材料により層を形成し，高機能舗装混合物の下 層に遮水性を持たせることや，表・基層間の接着引張強 度（性能）をゴム入りタックコート（PKR-T）に比べて高 めることを目的としている.

遮水型工法の施工には，通常，高濃度改質アスファル 卜乳剤の場合は，強制的に水とアスファルトの分離を促 す分解剂を同時散布する機能を備えた乳剂散布装置付き アスファルトフィニッシャーを用い ${ }^{2)}$ ，特殊改質アスフ アルトの場合は，専用のディストリビュータが使用され ている.

\section{3． 遮水型工法による基層の損傷抑制効果に関す る評価実験}

高機能舗装混合物を表層に適用した箇所における基層 の損傷としては，表層から浸透した水の影響により，上 面方向（表・基層の境界）からはく離が進行し脆弱化す る事象が挙げられる ${ }^{3)}$.また，ひび割れが発生していた既 設基層を存置した場合は，そのひび割れを起因とした基 層混合物自体の損傷進行や表層へひび割れが進展する事 象（リフレクティブクラックの発生）が挙げられる.

そこで，NEXCO で使用実績のある表-1 に示す種類の 遮水型工法を対象に，回転式舗装試験機を使用し，これ ら損傷等の再現を考慮した条件 (環境設定, 模擬供試体) により試験を行い，遮水型工法による基層の損傷抑制効 果について評価した.

\section{（1）基層のはく離進行抑制効果の評価}

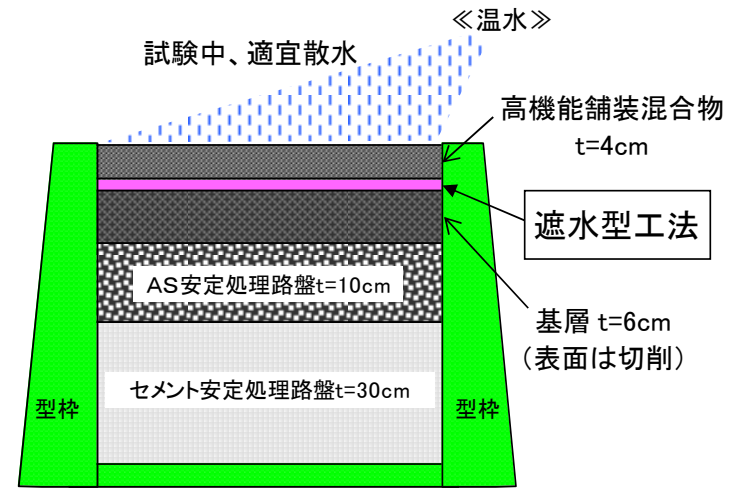

図-2 供試体の構成

表-2 試験条件

\begin{tabular}{|c|c|c|}
\hline 項 目 & \multicolumn{2}{|c|}{ 外軌道 } \\
\hline タイヤの種類 & $\begin{array}{l}\begin{array}{c}\text { 大型車タイヤ } \\
\text { (シングル) }\end{array} \\
\end{array}$ & 【散水条件】 \\
\hline 載荷重 & 2.5 & - 水温 $60^{\circ} \mathrm{C}$ \\
\hline$(\mathrm{km} / \mathrm{h})$ & 60 & $\begin{array}{l}\text { • 走行試験前および } \\
5000 \text { 輪毎に散水。 }\end{array}$ \\
\hline 路面温度 & $40 \sim 50$ & 散布量は約10L/ \\
\hline 累積走行輪数 （輪） & 54 万 & $\mathrm{m} \cdot$ 回 \\
\hline
\end{tabular}

\section{a) 試験概要}

本試験は，図-2 に示す供試体の舗装構成において，表 -2 に示す試験条件により実施した。 なお，基層上面から のはく離を促進させるため, 温水 $\left(60^{\circ} \mathrm{C}\right)$ を日々の走行 試験前と所定の走行輪数毎に，高機能舗装混合物の空隙 が十分に温水で満たされる程度, 路面に対し散布した。 また，基層面は，補修工事を想定し，切削を施した。

走行試験終了後は, 軌道部 (軌道部の位置は図-5 参照) から水浸ホイールトラッキング試験に準じ， $300 \mathrm{~mm} \times$ 300mm でブロックサンプリングし，基層断面のはく離面 積率を算出し評価した。また，遮水型工法を施工した混 合物の防水性を確認する目的で，供試体の外軌道部から 採取したコア試料（基層部を $2 \mathrm{~cm}$ 残して整形した表・基 層一体の試料）について，加圧透水試験を実施し，透水 係数を算出した. 加圧条件は、水圧 $150 \mathrm{kPa}, 24$ 時間加圧 した時点で透水が確認されなかった場合，更に水圧を $500 \mathrm{kPa}$ に変更し，引き続き 24 時間加圧を行った.

b）試験結果および考察

基層断面のはく離面積率を図-3 に，加圧透水試験結果 (透水係数) を図-4 に示す．なお，両図には，比較とし て同時に実施したゴム入りアスファルト乳剤 (PKR-T) お よび NEXCO で使用実績のあるタイヤ付着抑制型アスフ アルト乳剂（PKM-T）の試験結果も併記した.

遮水型工法を施工した基層においては，タックコート

（PKR-T，PKM-T）を施工した基層に比べ，はく離面積 率が小さく, 3 種類ともほとんどはく離が発生している状 況は確認できなかった. なお, はく離が確認された試料 は，いずれも基層上面から進行していた。 


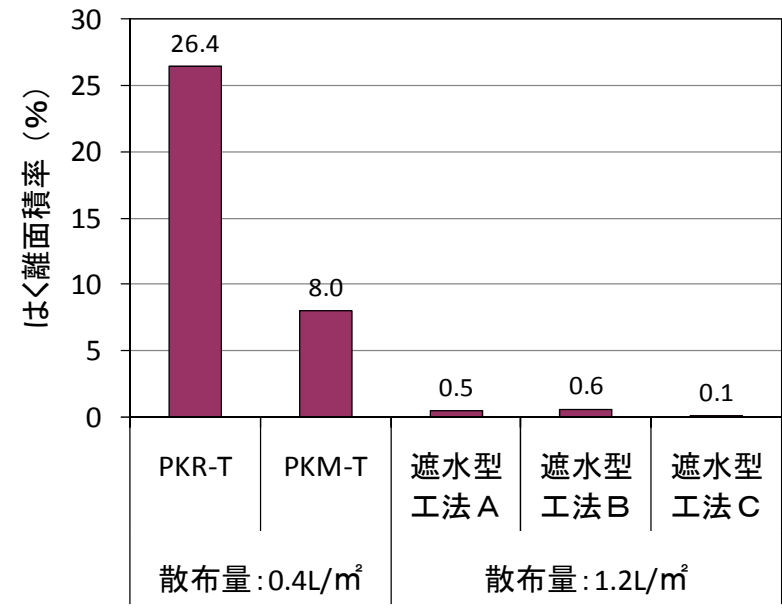

図-3＼cjkstart基層断面のはく離面積率

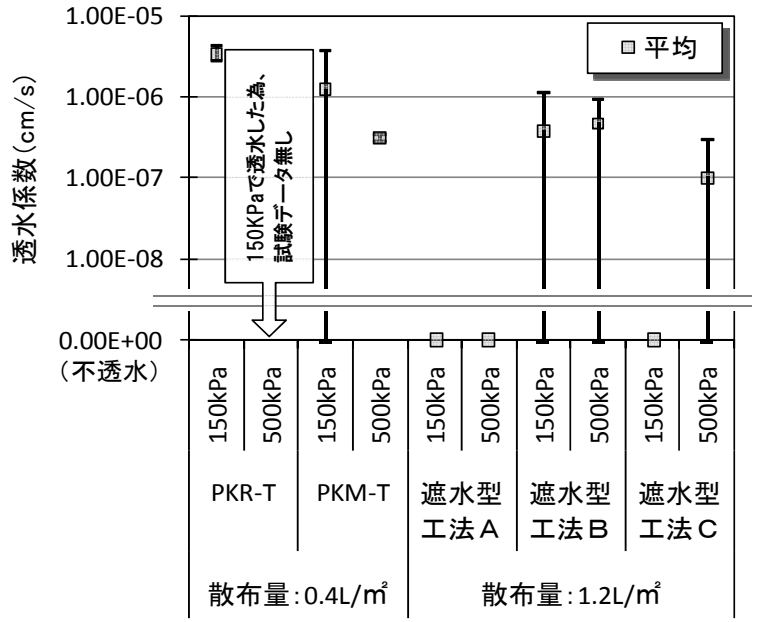

図-4 加圧透水試験による透水係数

表-3 供試体の構成

\begin{tabular}{|c|c|c|c|c|c|c|}
\hline \multirow{3}{*}{\multicolumn{2}{|c|}{ 舗装構成 }} & 試験条件 I & \multicolumn{4}{|c|}{ 試験条件 II } \\
\hline & & $A-1$ & $B-1$ & $B-2$ & $\mathrm{~B}-3$ & $B-4$ \\
\hline & & 【標準供試体】 & \multicolumn{4}{|c|}{ 【損傷模擬供試体】 } \\
\hline \multirow[t]{2}{*}{ 表 層 } & 混合物種別 & $\begin{array}{c}\text { 密粒度舗装 } \\
(13 \mathrm{~mm} \text {-タイプA) }\end{array}$ & \multicolumn{3}{|c|}{$\begin{array}{c}\text { 高機能舗装 } \\
(13 \mathrm{~mm} \text { - 空隙率 } 20 \%) \\
\end{array}$} & $\begin{array}{c}\text { 密粒度舗装 } \\
(13 \mathrm{~mm} \text { ータイプA) }\end{array}$ \\
\hline & 厚さ & $4 \mathrm{~cm}$ & \multicolumn{3}{|c|}{$4 \mathrm{~cm}$} & $4 \mathrm{~cm}$ \\
\hline \multirow{2}{*}{$\begin{array}{l}\text { アスファルト乳斉 } \\
\text { 遮水型工法 }\end{array}$} & 材料種別 & - & 遮水型工法A & 遮水型工法B & PKR-T & $\mathrm{PK}-4$ \\
\hline & 散布量 & - & $1.2 \mathrm{~L} / \mathrm{m}^{2}$ & $1.2 \mathrm{~L} / \mathrm{m}^{2}$ & $0.4 \mathrm{~L} / \mathrm{m}^{2}$ & $0.2 \mathrm{~L} / \mathrm{m}^{2}$ \\
\hline \multirow{3}{*}{ 基 層 } & 混合物種別 & \multicolumn{5}{|c|}{ 粗粒度舗装(20mm－基層用) } \\
\hline & 厚さ & $6 \mathrm{~cm}$ & \multicolumn{4}{|c|}{$5 \mathrm{~cm}$} \\
\hline & 模擬クラック & 無 & \multicolumn{4}{|c|}{ 有（かッター目地） } \\
\hline \multirow[t]{2}{*}{ 損傷想定層 } & 材料種別 & 無 & \multicolumn{4}{|c|}{$\begin{array}{c}\text { ゴム弾性舗装材 } \\
\text { （ウレタンバインダー＋加硫ゴムチップ[最大粒径2.5mm]＋硅砂3号） }\end{array}$} \\
\hline & 厚さ & - & \multicolumn{4}{|c|}{$1 \mathrm{~cm}$} \\
\hline \multirow{2}{*}{ 路 盤 } & 混合物種別 & \multicolumn{3}{|c|}{ 上層:アスファルト安定処理 (StAs60～80) } & \multicolumn{2}{|c|}{ 下層: セメン安定処理 } \\
\hline & 厚さ & \multicolumn{3}{|c|}{$10 \mathrm{~cm}$} & \multicolumn{2}{|l|}{$30 \mathrm{~cm}$} \\
\hline
\end{tabular}

遮水型工法を施工した混合物は, 図-4に示すようにタ ックコート (PKR-T, PKM-T) を施工した混合物に比べ, 繰返しの輪荷重の作用を受けた走行試験後であっても, 相対的に透水係数が小さくなっている. 特に, 高い加圧 条件（500kPa）の試験において不透水となった試料が確 認されていることから，遮水型工法を施工した混合物で は, 表面からの水が基層部へ浸透しにくい状態が走行試 験中担保され，基層のはく離進行を抑制したものと考え られる.

\section{（2）ひび割れ進行抑制効果の評価}

\section{a) 試験概要}

基層のはく離抑制効果については, 3 種類の遮水型工法 に明確な差異が見られなかったことから，本試験では， 主材料が乳剂タイプのもの，アスファルトタイプのもの それぞれ 1 種類（遮水型工法AおよびB）を対象に，下 層に損傷を模擬した供試体を使用して走行試験を行い, 路面性状等を観察することで，ひび割れ等の進行抑制効 果を評価することにした．損傷の模擬方法については， 実際のひび割れを定量的（定められた位置，長さ，幅， 深さ）に発生させることが困難であるため, コンクリー
トカッターで基層に目地切りする手法を用いた. また， 現場では，損傷の進行に伴って舗装のたわみ量が大きく

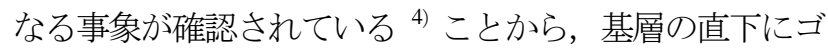
么弾性舗装材で構築した損傷想定層を設けることにより, 車輪通過時に生じるたわみ量が健全な舗装構造（標準供 試体）に比べ大きくなる状況を再現した.

本試験の供試体構成を表-3および図-5 に, 試験条件を 表-4 に示寸. なお, 当該の供試体構成は, 標準供試体と 数種類の損傷模擬供試体を使用した試験条件 I において, 累積走行輪数が概ね 50 万輪で表層（クラックが明確に確 認できるように密粒度舗装を適用）にリフレクティブク ラックが発生した供試体を参考とした．ここで，50 万輪 を目安にしたのは，試験が長期間に及ばないこと，なら びに基層のはく離進行抑制効果の評価試験における累積 走行輪数程度で, 標準供試体には損傷が発生しない条件 を考慮したからである。

各供試体の評価については, 日々の走行試験終了後に, 路面での損傷発生状況を観察するとともに，車輪走行軌 道部のたわ久量を小型 FWD（載荷板直径 $100 \mathrm{~mm}$, 重鍾 質量 $15 \mathrm{~kg}$, 落下高さ $30 \mathrm{~cm})$ により，わだち掘れ量を横断 プロフィルメータによりそれぞれ測定した. 


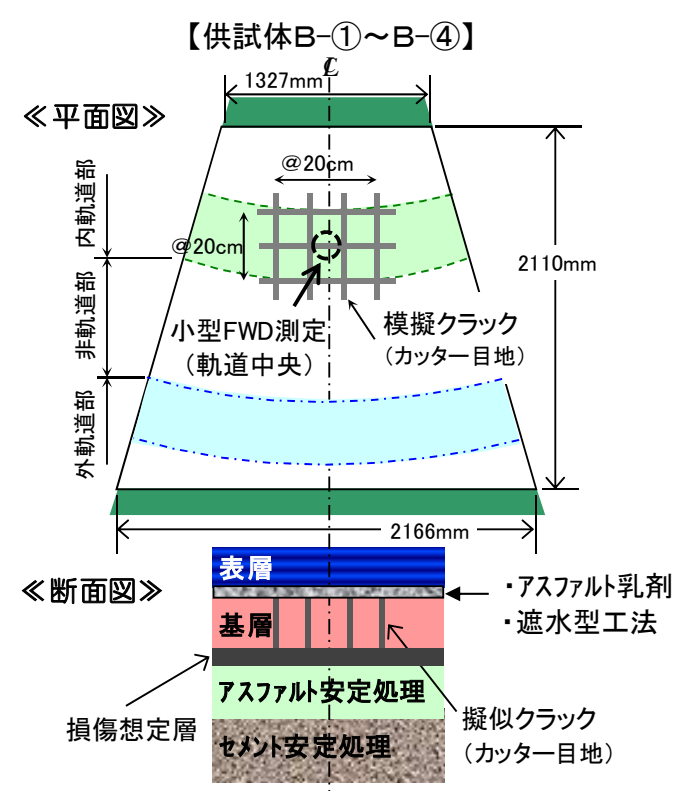

図-5 供試体の構成（試験条件II）

表-4 試験条件

\begin{tabular}{|c|c|c|c|c|c|c|}
\hline \multirow{2}{*}{\multicolumn{2}{|c|}{ 項 目 試験軌道等 }} & \multicolumn{4}{|c|}{ 試験条件 I （外軌道） } & \multirow{2}{*}{$\begin{array}{l}\text { 試験条件 II } \\
\text { (内軌道) } \\
\end{array}$} \\
\hline & & パターン1 & パターン2 & パタ-ン3 & パターン4 & \\
\hline \multicolumn{2}{|c|}{ タイヤの種類 } & \multicolumn{4}{|c|}{$\begin{array}{c}\begin{array}{c}\text { 大型車夕イヤ } \\
\text { (シングル) }\end{array} \\
\text { (ジ) }\end{array}$} & $\begin{array}{c}\text { 大型車ダイ } \\
\text { (シングル) }\end{array}$ \\
\hline 載荷重 & (ton) & \multicolumn{4}{|c|}{2.5} & 2.5 \\
\hline 速 度 & $(\mathrm{km} / \mathrm{h})$ & 20 & 40 & \multicolumn{2}{|c|}{40} & 60 \\
\hline \multicolumn{2}{|l|}{ 散水条件 } & \multicolumn{3}{|c|}{ 無 } & 常時散 & 常時散水 \\
\hline 路面温度 & $\left({ }^{\circ} \mathrm{C}\right)$ & \multicolumn{2}{|c|}{$10 \sim 15$} & $20 \sim 25$ & 20 & $10 \sim 20$ \\
\hline \multirow{2}{*}{$\begin{array}{l}\text { 累積走行 } \\
\text { 輪数 }\end{array}$} & \multirow{2}{*}{ （輪） } & 9.5 万 & 13.5 万 & 17 万 & 10万 & \multirow{2}{*}{ 44万 } \\
\hline & & \multicolumn{4}{|c|}{ 50万 } & \\
\hline
\end{tabular}

\section{b） 試験結果および考察}

各供試体の小型 FWD による載荷点直下のたわみ量お よび路面の最大わだち掘れ量の推移を図-6～図-7 に示寸. 同図には，二つの試験条件の結果を併記している.

表層に高機能舗装混合物, 基層にタックコート(PKR-T) を適用した供試体（B-(3)）は，他の供試体に比べ，たわ み量，わだち掘れ量ともに増加進行が大きく，走行試験 終盤では路面の陷没等著しい変状が生じ，35 万輪以降計 測不能となった.

表層に密粒度舗装混合物を適用した供試体 (B-4) は, 10 万輪走行時点で路面にひび割れの発生が確認され，そ の後は，模擬クラックに沿ったかたちでひび割れが拡大 するとともに，たわみ量が増加した。

表層に高機能舗装混合物，基層に遮水型工法を適用し た供試体（B-(1)，B-(2)）は，30 万輪走行時点まで主立っ た路面の変状は見られなかった。しかし，たわみ量につ いては，他の供試体に比べ傾向は緩やかなものの，走行 輪数が累積するにつれ，徐々に増加し，わだち掘れ量に ついても，温度影響が少ない（常温下）にも拘わらず， ひび割れ等の変状が生じた供試体（B-4)）と同様に増加 進行が大きくなった．表層混合物や試験条件に違いはあ るものの，試験条件 I において舗装構造が比較的健全な

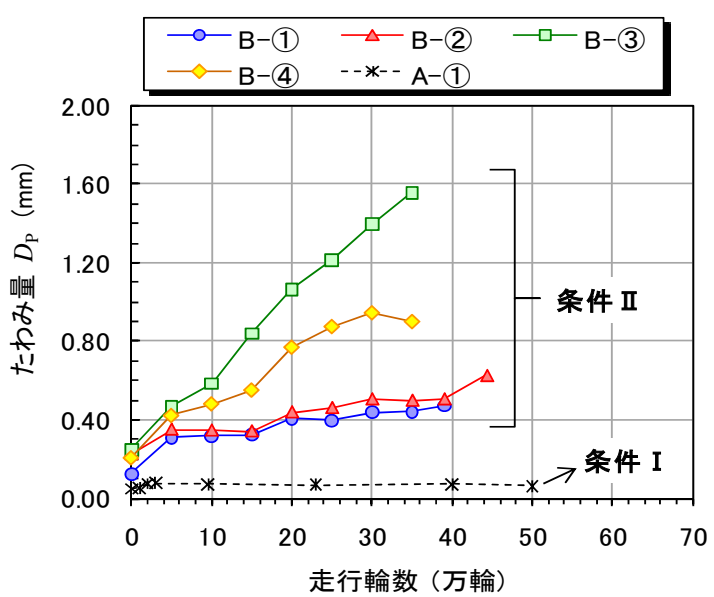

図-6 たわみ量の推移

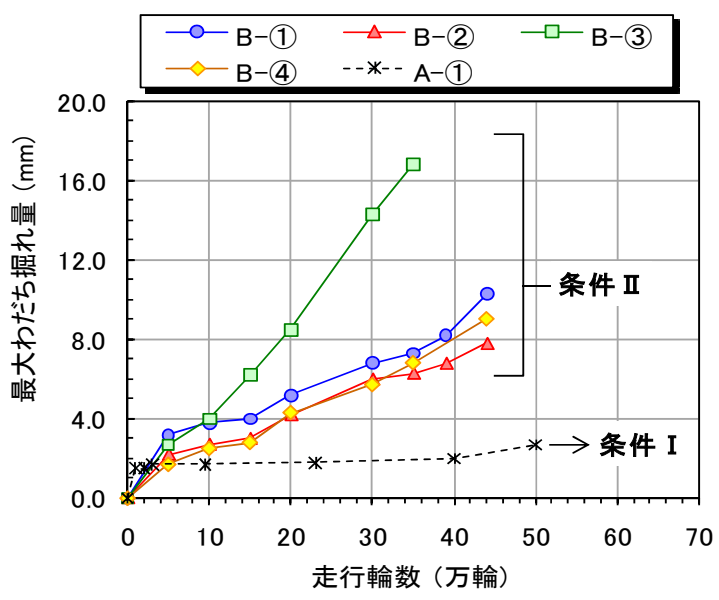

図-7 最大わだち掘れ量の推移

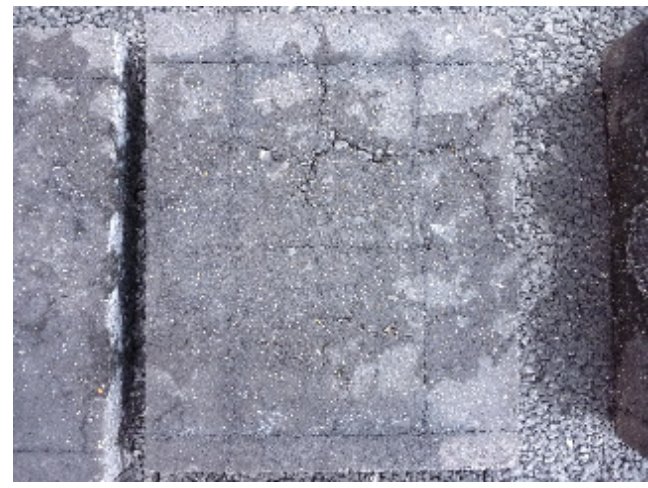

写真-1 採取試料の状況（供試体 B-(1)の例）

場合は，たわみ量の増加やわだち掘れ量に顕著な進行が みられないことを考慮すると，基層等の下層部で損傷が 進行している状態がこれらの事象から推察された。

そこで，下層部の損傷状況を確認するため，走行試験 終了後に，基層に遮水型工法を適用した供試体（B-(1), B-(2)）の軌道部からブロックサンプリングを行い，基層 部の状態を観察した。 その結果，両試料とも写真-1（写 真は基層の下面を表側にして撮影）に示寸ように，直線 的な模擬クラック（カッター目地）以外に，路面上で把 


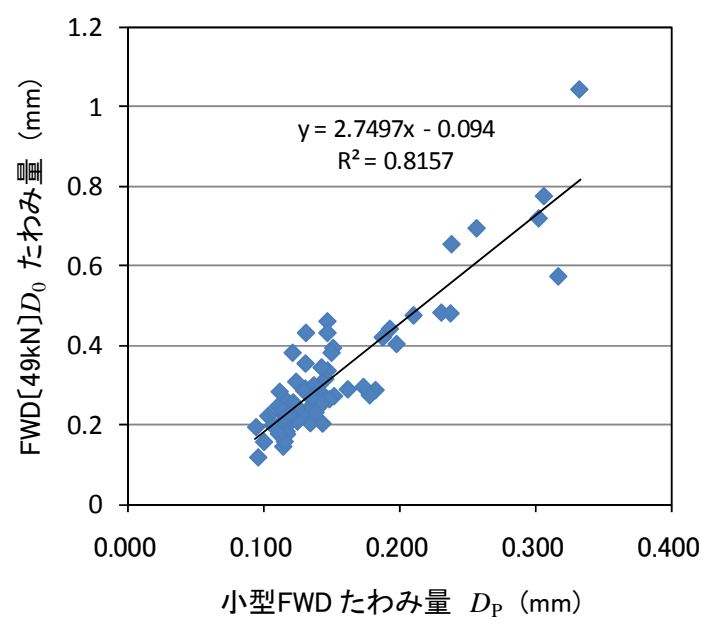

図-8 小型FWDとFWDのたわみ量の関係

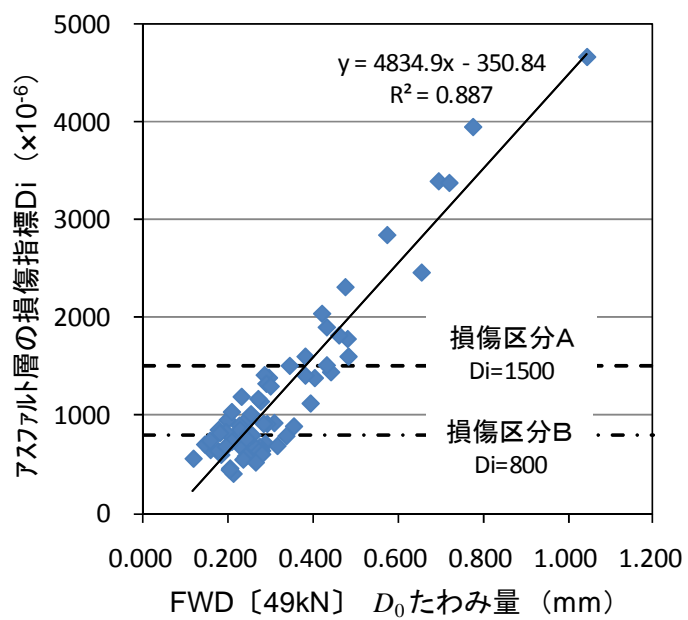

図-9 $\quad D_{0}$ たわみ量と Di の関係

握できなかった不規則な形状をしたひび割れが多く発生 している状況を確認した．このことから，基層部では， 実際に損傷が進行していたことが判明した.

\section{c) 損傷の進行に関する推察}

損傷の進行を確認したことから，基層に遮水型工法を 適用した供試体 (B-(1) 作製時に模擬した損傷の程度と， その後走行試験によって進行した同供試体の損傷の程度 を，次のとおり高速道路本線の損傷状態に当てはめて想 定することを試みた。

供試体の評価に使用した小型 FWD 測定器を用い同じ 荷重設定により, 高速道路本線（舗装構成＝高機能舗装， 粒状路盤, アイファル層厚 : 18～20cm, 舗装全厚 : $40 ５ 0 \mathrm{~cm}$ ) を測定した載荷点直下のたわみ量 $\left(D_{\mathrm{P}}\right)$ と, 同一箇所で 同一日（路面温度 : $10^{\circ} \mathrm{C}$ 程度）に FWD 測定（荷重設定： $49 \mathrm{kN})$ し，荷重および温度 $\left(20^{\circ} \mathrm{C}\right)$ 補正を行ったたわみ 量 $\left(D_{0}\right)$ の関係を図-8 に示す.このたわみ量の関係から, 小型 FWD 測定によるたわみ量 $\left(D_{\mathrm{P}}\right)$ に相当寸る FWD 測 定によるたわみ量 $\left(D_{0}\right)$ 求め, 次にその $D_{0}$ と同たわみ測

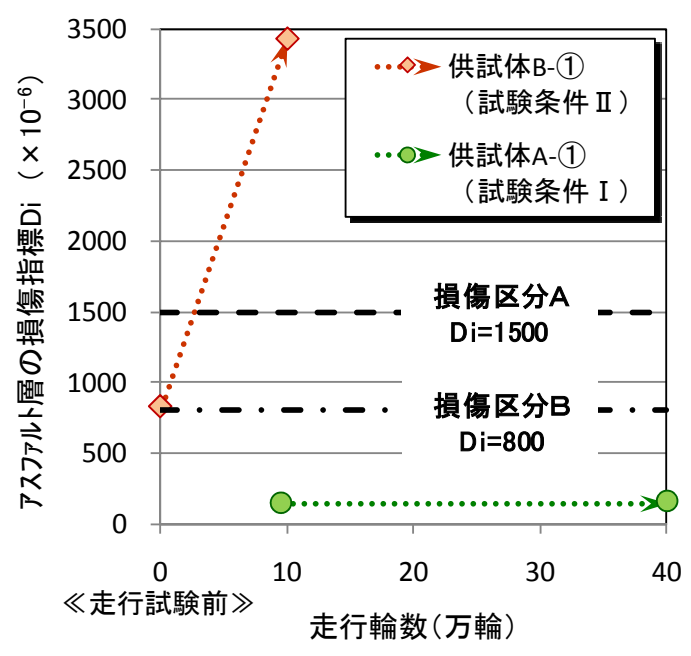

図-10 Di（想定值）の推移

表-5 アスファルト層の健全度評価区分

\begin{tabular}{|c|c|}
\hline 評価区分 & 想定される損傷層 \\
\hline \hline 損傷区分 $\mathrm{A}$ & アスファルト層全層 \\
\hline 損傷区分B & 表層および基層 \\
\hline 損傷区分 $\mathrm{C}$ & 表層(構造としては健全) \\
\hline
\end{tabular}

定データから算出したアスファルト層の損傷指標（Di） の関係（図-9）から， $D_{0}$ に相当する Di を求める手順で, $D_{\mathrm{P}}$ から Di を想定した.

ここで，アスファルト層の損傷指標（Di）とは，アス ファルト層の損傷状況を舗装構成，アスファルト層の厚 さから評価する指標であり ${ }^{4)}$, NEXCO の設計要領 ${ }^{5)} に は$, 本指標に基づく評価区分が表-5 のとおり定められている.

基層に遮水型工法を適用した供試体（B-(1)）と構造的 に健全な標準供試体（A-1)）の Di（想定值）の推移を図 -10 に示寸.この Di の推移を評価区分で表すと，供試体 （B-11）の走行前の状態は，「損傷区分 B」の臨界域に, 10 万輪通過時では「損傷区分 $\mathrm{A} 」 に$ 判定され，Di の変化 （増加）が非常に大きくなっている．それに比べ標準供 試体（A-(1)）のDi は小さく, 変化も無い状態で試験中推 移していることから，構造的な損傷が進行しない健全な 状態が担保されていることがわかる.

実道（高速道路）に対寸る健全度評価区分を，試験供 試体一適用寸ることの可否は別として，図-6 に示寸遮水 型工法を適用した供試体（B-1)，B-(2)）のたわみ量の増 加推移は，アスファルト層の構造的な損傷が進行してい る状況であることが，この試行からも推察できる.

以上のことから，損傷した基層上に遮水型工法を施工 しても，繰返しの交通荷重等の作用によって基層部を中 心に構造的な損傷は進行していく可能性が高いと考えら れる. この傾向は, 構造的な損傷が生じている箇所で, 密粒度舗装混合物等で表層の夕を補修した場合も同様と 考えられる. 


\section{4. 遮水型工法の施エによるアスファルト層の構 造的な強度への影響}

遮水型工法の施工によるアスファルト層の構造的な強 度への影響と経時変化を確認するため, 高速道路本線の 施工箇所において FWD 測定により追跡調査を行ってい る.このうち, 今回の分析対象箇所として, 遮水型工法 の施工前直近の測定データを有する区間を選定し，遮水 型工法施工時のアスファルト層の構造的な健全度 (強度) の違いによる供用後の健全度の変化状況を確認した.

選定した 2 区間の追跡調査結果を図-11〜図-12 に示寸， 両区間とも遮水型工法（遮水型工法A）のみで，基層以 深の補修は行っていない. なお，同図ではアスファルト 層の健全度を表すため, FWD 測定值を前出のアスファル 卜層の損傷指標（Di）で示している.

2 区間とも施工前に比べ，施工 1 年後に Di の值が大き くなる傾向となっている. また，施工前の Di の值が，評 価区分の「損傷区分 $\mathrm{B} 」$ 以上に該当寸る箇所では，経年 によるたわみ量の増加が特に大きくなっている箇所が存 在している (図中の矢印部)。前章の回転式舗装試験機を 使用した評価実験の状況から，このようにたわみ量の増 加が大きくなっている箇所については，交通荷重等の作 用によって，損傷が進行していることが考えられる.

これらの傾向から，遮水型工法を施しても，舗装の構造 的な強度にはほとんど寄与していないことがわかる。ま た，基層以深の補修を行わない場合は，施工前の舗装の 状態（健全度）によって，供用後の構造強度の持続性に 違いが生じる可能性がうかがえる.

\section{5. まとめ}

本検討の結果ならびに考察をまとめると, 以下のとお りである。

1）回転式舖装試験において, 損傷が無く健全な基層部に 遮水型工法を施工した場合，タックコート（PKR-T,

PKM-T）を施工した場合に比へ，基層部のはく離進行 を抑制させる効果が高いことを確認した. これは, タ ックコートに比べて多量に散布される材料で形成さ れる層の効果により, 繰返しの輪荷重の作用を受けて も比較的低い透水係数が維持され，表面からの水が基 層部一浸透しにくい状態が, 走行試験中担保されたこ とが要因として考えられる.

2）回転式舗装試験において, 基層部に損傷を模擬し遮水 型工法を施工した供試体は, 遮水型工法を施工してい ない供試体に比べ, 傾向は緩やかであるものの, 走行 輪数の累積に伴いたわみ量, わだち掘れ量がともに増 加することを確認した. 同試験で舗装構造が比較的健 全な供試体では, 走行輪数の累積に伴うたわみ量, わ だち掘れ量に顕著な進行がみられないことや, 走行試

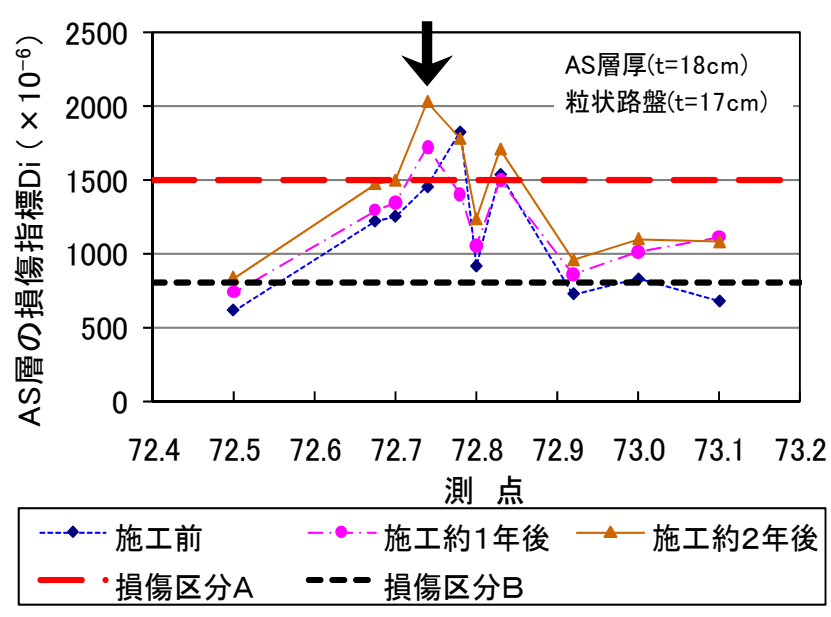

図-11 Di の経年変化（施工箇所A）

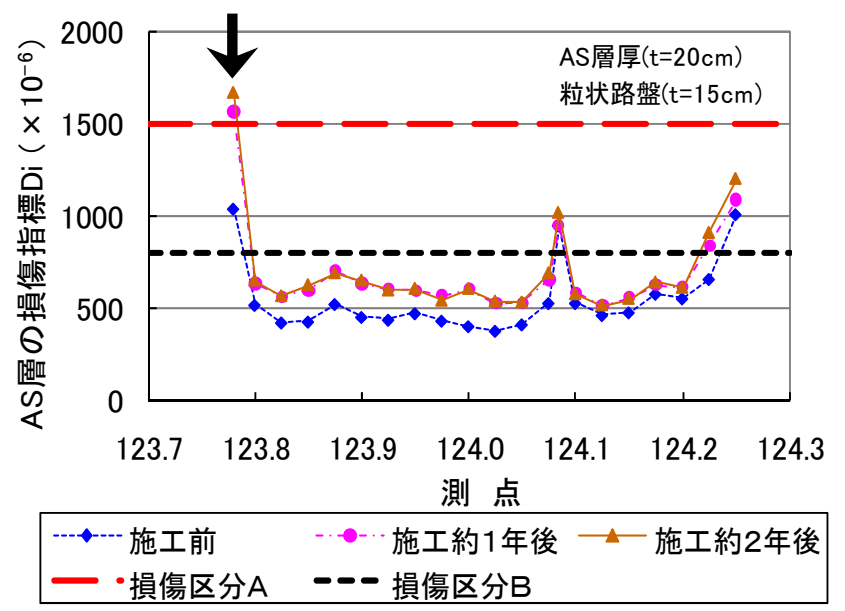

図-12 Di の経年変化 (施工箇所B)

験後に遮水型工法を施工した供試体でブロックサン プリングした基層においてひび割れが進展している 状態を確認した. これらより, 損傷した基層上に遮水 型工法を施工しても, 繰返しの交通荷重等の作用によ って基層部を中心に構造的な損傷は進行していく可 能性が高いことが考えられる.

3) 高速道路本線に遮水型工法が施工された代表箇所に おける FWD 測定による追跡調査結果から，施工前に 比べ，施工 1 年後にアスファルト層の損傷指標 $(\mathrm{Di})$ の值が大きくなる傾向を確認した．また，施工前の $\mathrm{Di}$ の值が，評価区分の「損傷区分 B」以上に該当寸る 箇所では, 経年によるたわみ量の増加が特に大きくな る場合があることを確認した. これらより, 遮水型工 法を施しても, 舗装の構造的な強度にはほとんど寄与 しないため, 基層以深の補修を行わない場合は, 施工 前の舗装の状態（健全度）によって, 供用後の構造強 度の持続性に違いが生じる可能性が考えられる。 


\section{6. 遮水型工法の適用について}

本検討により得られた知見から考えられる，遮水型工 法の適用条件や留意点等を以下に示す.

健全な舗装構造において遮水型工法が適用された場合 は，基層上にタックコート（PKR-T，PKM-T）を適用し た場合に比べ，基層部のはく離進行が抑制されると考え られる. しかし，はく離に伴う基層の脆弱化による損傷 は，はく離抵抗の低い材料・配合が使用された箇所が主 体であることから，はく離抵抗性の高い材料・配合を使 用した基層等に対し，更に遮水型工法を適用することの 効果を定量的に示すことは難しい.

このため, 新設時や損傷が表層部のみの補修時など, 健全な舖装構造において遮水型工法を適用するケースと しては，はく離の進行が助長される次に示すような条件 が考えられる.

・ サグ部，反向点部など，高機能舗装混合物に雨水等が 滞水し易い箇所.

$\Rightarrow$ 水の浸透リスクの高い箇所における基層等の防 水性の向上

- 舗装構造としては健全であるものの, 存置する既設基 層混合物のはく離抵抗性が魙念される場合.

$\Rightarrow$ 水の浸透を抑制することで基層混合物の性能を 担保

一方, FWD 調査や採取コア等による評価において基層 以深に損傷が確認され，かつ当該の基層以深を存置した かたちで遮水型工法が適用された場合については，次の 点に留意する必要があると考えられる.

表面からの雨水等は，遮水型工法を適用しない場合に 比べて下層へ浸透しにくいため, 遮水型工法を施工した 直後などの損傷程度が比較的低い段階までは，急速な損 傷の進行は緩和される可能性はある。しかし，遮水型工 法を施工しても舗装の構造的な強化は図れないため, 水
の浸透が抑制されていても, 繰返しの交通荷重等の作用 によって基層部を中心に構造的な損傷は徐々に進行して ゆき，特に交通量の多い路線では，基層等が健全な場合 に比べて比較的早期に表層を含むかたちで損傷が顕在化 することが懸念される.

よって, 遮水型工法の適用に際しては, 対象箇所の舗 装構造等を十分に把握し, 上記の特徵を踏まえ, 適用を 判断することが重要であると考えられる.

\section{7. おわりに}

舗装の修繥については，損傷の状態，環境条件や路線 の特性，補修目的などが多様であり，補修方法等が一義 的に定まるものではない. よって, 遮水型工法の適用に ついても，前章に述べた内容がすべてではなく，工法の 特徵を踏まえ, 補修目的を明確にすることで, 様々なケ 一スへの適用も考えられると思っている.

最後に，本報告が舗装補修の現場等に従事されている 方々の参考となれば幸いである.

\section{参考文献}

1) 川村和将, 神谷恵三 : NEXCO における舗装補修の現状と 課題, アスファルト, Vol.50 No.222, 2007.10

2) 樫野誠, 井上彰, 伊藤春彦, 松村高志, 松本大二郎 : 遮水 型排水性舗装工法の開発，道路建設，No.688，2005.7.

3）本松資朗，神谷恵三，松本大二郎，山田優 : 既設基層混合 物のはく離抵抗性の評価方法に関する研究，土木学会舗装 工学論文集第 9 巻, pp.73-79, 2004. 12

4) 風戸崇之, 神谷恵三 : 高速道路哺装の補修設計に関する研 究, 土木学会舗装工学論文集第 15 巻, pp.73-79, 2010.12

5）東日本高速道路㑣，中日本高速道路森，西日本高速道路㑣： 設計要領 第一集 舗装編, 2010.7

\section{A STUDY ON EFFECT OF PREVENTION FROM BINDER LAYER'S DISTRESS UNDER POROUS ASPHALT SURFACE LAYER USING LARGE AMOUNTS OF HIGHLY CONCENTRATED MODIFIED EMULSION OR MODIFIED ASPHALT}

\section{Daijiro MATSUMOTO,Ryo KATO,Masakazu SATO and Keizo KAMIYA}

This study is to evaluate whether or not a highly concentrated modified emulsion or a specially modified asphalt will prevent porous asphalt surface layer's underlying binder layer from getting deteriorated. Judging from full-scale accelerated pavement testing, both of the materials can be more preventive to the binder layer's segregation than conventional emulsions, in case there is no defect in the original binder layer. If the original binder layer is a lready defected, however, the layer tends to be further defected due to repeated traffic loads, although the two materials can retard the distress at early traffic stages. Based on these results, applicability of the materials in the field are to be considered. 